\title{
Factors Explaining Firm Investment: An International Comparison
}

\author{
Ben Said Hatem ${ }^{1}$ \\ ${ }^{1}$ Faculty of Law, Economics and Management of Jendouba, University of Jendouba, Jendouba, Tunisia \\ Correspondence: Ben Said Hatem, Faculty of Law, Economics and Management of Jendouba, University of \\ Jendouba, Jendouba, Tunisia. E-mail: hatmbensaid@gmail.com
}

Received: April 19, 2015

Accepted: November 19, 2015

Online Published: December 25, 2015

doi: 10.5539/ibr.v9n1p112

URL: http://dx.doi.org/10.5539/ibr.v9n1p112

\begin{abstract}
This paper examines the determinants of firm investment decision. Our study analysed four countries: Moldova, Romania, Russia and Serbia. The sample contains 170 firms for each country for a period of 8 years from 2003 to 2010. Using the data panels method, the empirical results indicate that profitability positively and significantly influences the firm investments for the markets of Moldova and Romania under two alternatives, and for the other countries under one specification. However, the positive effect of cash holdings is only observed for the firms of Moldova and Serbia. Furthermore, the higher the size of the firms of all countries is, the more the managers are encouraged to invest more. Finally, the sensitivity analysis of our models on activity sectors, shows differences in the factors explaining the investment decision for the market of Moldova. Indeed, profitability significantly and positively explains firm investment for the service and real estate sectors. This result is found for other countries for two sectors. In contrast, for country Russia, an increase in the profitability for mining and agriculture firms, does not stimulate managers to invest more.
\end{abstract}

Keywords: firm investment, determinants, firm age, profitability, activity sectors

\section{Introduction}

The investment decision is a very important financial decision for the firm (Aghion \& Howitt, 1992). Investment decision can favourably affect shareholder wealth. Therefore, it is important to test the factors behind this decision (Bhagat \& Welch, 1995; Bond, Harhofff, \& Van Reenen, 2005; Singh \& Faircloth, 2005; Czarnitzki \& Hottenrott, 2010). Kaplan and Zingales (1997) highlight that the cash fows, and firm size significantly affect the investment decision. Similarly, Cleary (1999) and Fazzari et al. (1988) assume that investment of a firm depends heavily on the presence of cash holdings. Lai Yung Feng and Lin (2015) test factors explaining investment in intangible assets. The empirical validation was done on three countries; Taiwan, Korea and Japan. They conclude that, for the cases of Japan and Korea, non-statistically significant effects of profitability and capital structure on investment decision. However, in the case of Taiwan, the authors highlight a significant effect of profitability on investment. Similarly to the work of Bond and Meghir (1994); Bond et al. (2003); Brown et al. (2009); James Brown, Bruce, and Petersen (2014) identify the determinants of firm investment. They consider as independent variables, sales, cash holdings, cash flows, changes in cash holdings and equity issues. The empirical results highlight significant influences of cash flow and cash holdings on firm investment. Similarly, Duchin et al. (2010) test the association between investment and cash flows. The same way, this study tries to test the determinants of firm investment decision. The empirical examines three countries: Romania, Russia and Serbia. The next section will review the main studies that highlight the factors explaining the investment decision. In Section 3, we introduce our sample, tested models and our variables. Section 4 highlight the descriptive statistics and our empirical results. A sensitivity analysis of our results by sectors is made in section 5. The last section concludes with our main results.

\section{The Literature Review}

In line with the work of Heshmat (2002), Dany and Hwang (2008) test the determinants of investment for ICT firms. The authors use different variables to measure the investment; investment in tangible assets ratio, total debt over total assets ratio. The authors test an adjustment model of investment decision. They consider the investment target as determined by all factors including, debt ratio, firm cash flows, firm size and activity sectors. The sample consists of 2782 companies listed on the US market for a period of 11 years from 1995 to 2005. The authors identify the determinants of investment using two samples of firms. They conclude that the effect of cash flows on investment decision is independent of activity sectors of firms. On the other side, they conclude that firm size 
negatively affects firm investment.

Like Chen (2001), Clark (2003), Liu and Sun (2005), Qi and al. (2000), Xu and Wang (1999), Alex, Hong Zhang, and David (2013) tried to empirically test the impact of ownership concentration and the controlling shareholder on the investment decision of a firm using a sample of 786 non-financial firms in the China market over a period of 7 years from 1998 to 2004. The authors use several alternative measures of investment, including cash flows and sales. To measure ownership concentration, the authors use the share of capital owned by shareholders and the share of capital of the largest 5 and 10 shareholders. The authors measured ownership concentration using the Herfindahl index. By testing the dynamic panel data method as described by Arellano and Bond (1991), Arellano and Bover (1995) and Blundell and Bond (1998), the authors highlight to a non-significant effect of cash flows of the firm on investment decision. However, the authors conclude that ownership structure can explain firm investment.

\section{Data and Methodology}

\subsection{Sample Selection}

The data in our sample are extracted from the Amadeus DATABSAE. Our sample consists of 170 firms of Moldova, 170 firms of Romania, 170 firms of Russia and 170 firms from Serbia for a period of 8 years from 2003 to 2010 .

\subsection{Choice of Variables and Hypothesis}

The dependent variable:

Firm Investment: To measure firm investment, Harford (1999) use a probit model to identify the likelihood that a firm will engage in a new acquisition. However, in our article, and according to the work of Fazzari and al. (1988), Hoshi et al. (1991) and Almeida et al. (2004), Massimo, Annalisa, and Massimiliano (2013), we use a dependent variable, alternatively, three measures:

- The first variable measures the investment as the changes (measured by growth rate) of total assets of the firm.

- The second variable measures the investment as the changes (measured by growth rate) of tangible fixed assets.

- The second variable measures the investment as the changes (measured by growth rate) of intangible fixed assets.

The independent variables:

Profitability: Taeyoung and Taeyoon (2015) measures profitability using return on equity ratio. However, and like David et al. (2014), we measure profitability as the following ratio of Net income divided by the value shareholders funds. A higher profitability of firms causes more liquidity available. According to the Free Cash Flows theory of Jensen (1986), the owners try to minimize agency costs of shareholders equity by changing firm investments. The coefficient on this variable is expected to be positive. Hypothesis 1: The profitability positively affects firm investment.

Liquidity: Like James and Bruce (2014), we measure the liquidity effect on firm investment. Liquidity is measured as the ratio of cash holdings of the firm over total assets (David Audretsch \& Elston, 2002). Indeed, a large amount of liquidity will stimulate managers to invest more. Therefore, the coefficient on the liquidity variable is expected to be positive. Hypothesis 2: Liquidity positively affects firm investment.

Firm size: Kadapakkam, Kumar, and Riddick (1998) measure firm size as log of sales over fixed tangible assets. However, in this study, size is identified by the logarithm of the total assets. Indeed, information asymmetry is decreasing function of firm size (Rajan \& Zingales, 1995). Thus, managers can get sources of funding (debt or equity) to finance investment. The coefficient on the variable size is expected to be positive. However, the larger the firm is, the less interested managers are in increasing the asset value of their firms. Hypothesis 3: Size affects positively or negatively firm investment.

Firm age: Like Rebecca Zarutskie (2006) and Kazuo Ogawa (2015), we measure the effect of firm age on firm investment behaviour. Firm age is approximated by the period between the current date and the foundation year. Indeed, the higher the firm age is, the higher the firm is recognized, which will encourage managers to increase the size of their firms through investment. Hypothesis 4: firm age negatively affects firm investment. 
Table 1. Variables and expected signs

\begin{tabular}{cccc}
\hline Variables & Abbreviation & Formulation & Expected sign \\
\hline Firm investment & INVTA & growth rate of total assets & Dependant variable \\
Firm investment & INVTANG & growth rate of tangible fixed assets & Dependant variable \\
Firm investment & INVINTANG & growth rate of intangible fixed assets & Dependant variable. \\
Profitability & PROF & Net income / Shareholders equity & + \\
Liquidity & LIQ & Cash holdings/ TA & Ln(TA) \\
Firm Size & SIZE & number of years between the current date and the foundation year. \\
Firm age & AGE & & - \\
TA: total assets. & & &
\end{tabular}

\subsection{Models to Be Tested}

Like Richard Bilsborrow (1977), Lai Yung, Feng, and Yi (2015) and Farla (2014) and and based on discussion above, we try to test following models to identify factors affecting firm investment;

$$
\begin{aligned}
& I_{N V T A}=\alpha_{0}+\alpha_{1} \text { PROF }_{i t}+\alpha_{2} \text { LIQ }_{i t}+\alpha_{3} \text { SIZE }_{i t}+\alpha_{4} A G E_{i t}+\varepsilon_{i t} \\
& I_{N V T A N G}=\alpha_{0}+\alpha_{1} \text { PROF }_{i t}+\alpha_{2} \text { LIQ }_{i t}+\alpha_{3} \operatorname{SIZE}_{i t}+\alpha_{4} A G E_{i t}+\varepsilon_{i t} \\
& \text { INVINTANG }_{i t}=\alpha_{0}+\alpha_{1} \text { PROF }_{i t}+\alpha_{2} \text { LIQ }_{i t}+\alpha_{3} \operatorname{SIZE}_{i t}+\alpha_{4} A G E_{i t}+\varepsilon_{i t}
\end{aligned}
$$

\section{The Empirical Results}

\subsection{Descriptive Statistics}

The distribution of our sample into five sectors: Service sector, real estate activities, professional, scientific and technical activities, mining and agriculture activities and manufacturing activities are presented in Table 2 .

Table 2. Distribution of our sample into activity sectors

\begin{tabular}{ccccccc}
\hline & Service & Real estates activities & Professionals activities & $\begin{array}{c}\text { Mining and } \\
\text { agriculture }\end{array}$ & Manufacturing & Total \\
\hline Moldova & 45 & 51 & 8 & 8 & 58 & 170 firms \\
Romania & 32 & 21 & 6 & 33 & 78 & 170 firms \\
Russia & 18 & 10 & 31 & 5 & 106 & 170 firms \\
Serbia & 45 & 38 & 7 & 9 & 71 & 170 firms \\
\hline
\end{tabular}

The sample of Moldova is described ass follow: 45 firms in service sector, 51 companies in real estate sector, 8 firms in professionals activities, 8 firms in mining and agriculture sector and 58 industrial companies. A significant part of firms belongs to industrial sector. For the country of Romania : 32 firms in services sector, 21 companies in the real estate sector, 6 firms in professional activities, 33 firms in mining and agriculture and 78 industrial companies. These results show that for the country of Romania, most firms belongs to the mining, agriculture and industrial sectors. A significant part of firms belongs also to the service business. For the country of Russia, firms are introduced as follows: 18 firms in the service sector, 10 firms in the real estate sector, 31 firms in professional activities, 5 mining and agriculture companies and 106 industrial firms. These results show that the majority of firms belong to the manufacturing and Professionals activities sectors. However, the lowest part of firms is concentrated in the mining and agriculture sector. Regarding the country Serbia, firms are introduced as follows: 45 companies belong to the service sector, 38 firms to the real estate sector, 7 firms in professionals activities, 9 firms to the mining and agriculture sector and 71 industrial companies.

The results of descriptive statistics (Table 3) indicate that the country Romania has a positive average profitability equal to 0.0220 , with a minimum of -0.980 and a maximum of 0.988 . Furthermore, Russia has a positive average return of 0.100 with a minimum of -0.946 and a maximum of 0.992 . The other countries have an average deficit profitability. The high profitability ratio for the Russian firms explains the high liquidity ratio that is equal 0.0379 . However, firms in Moldova have of the lowest liquidity ratio. Regarding firm size, we found that firms in Russia 
have the highest medium sized equal to 16,835 . This value is lower than that found by David and Julie (2002). However, the Moldovan firms have the smallest size. Finally, firms in Russia are the Mature companies with an average age of 35,687 years with a minimum of one year and a maximum of 293 years. This average age is higher than that found by Massimo, Annalisa, Massimiliano (2013) for Italian firms (they an average age equal to 10.38 years for a sample of 288 firms observed from 1994 to 2008). For investment variables, we found a higher growth of total assets for firms from Romania with an average value of 0.245 .

Table 3. Descriptive statistics

\begin{tabular}{|c|c|c|c|c|c|}
\hline \multicolumn{6}{|c|}{ Moldova } \\
\hline & OBS & MEAN & STD DEV & MIN & MAX \\
\hline PROF & 911 & $-0,00270$ & 0,167 & $-0,919$ & 0,945 \\
\hline LIQ & 914 & 0,0215 & 0,0624 & 0,000000366 & 0,917 \\
\hline SIZE & 926 & 12,257 & 1,918 & 6,563 & 18,0558 \\
\hline AGE & 1354 & 12,444 & 2,722 & 1 & 19 \\
\hline INVTA & 704 & 0,0423 & 0,348 & $-0,967$ & 3,455 \\
\hline INVTANG & 312 & 3,767 & 20,630 & -1 & 167,264 \\
\hline INVINTANG & 666 & 0,208 & 6,711 & -1 & 11,862 \\
\hline \multicolumn{6}{|c|}{ Romania } \\
\hline & OBS & MEAN & STD DEV & MIN & MAX \\
\hline PROF & 1167 & 0,0220 & 0,230 & $-0,980$ & 0,988 \\
\hline LIQ & 1243 & 0,0681 & 0,115 & 0,000000658 & 0,888 \\
\hline SIZE & 1253 & 14,706 & 2,680 & 7,0211 & 19,534 \\
\hline AGE & 1319 & 15,161 & 3,959 & 1 & 21 \\
\hline INVTA & 1037 & 0,245 & 1,261 & $-0,907$ & 32,0241 \\
\hline INVTANG & 1033 & 0,668 & 7,997 & -1 & 232,0591 \\
\hline INVINTANG & 559 & 4,436 & 41,447 & -1 & 686,531 \\
\hline \multicolumn{6}{|c|}{ Russia } \\
\hline & OBS & MEAN & STD DEV & MIN & MAX \\
\hline PROF & 1193 & 0,100 & 0,185 & $-0,946$ & 0,992 \\
\hline LIQ & 1229 & 0,0379 & 0,0661 & 0,0000013 & 0,903 \\
\hline SIZE & 1235 & 16,835 & 0,922 & 13,797 & 24,0831 \\
\hline AGE & 1351 & 35,687 & 42,858 & 1 & 293 \\
\hline INVTA & 1058 & 0,161 & 0,464 & -1 & 9,382 \\
\hline INVTANG & 1054 & 0,113 & 0,413 & -1 & 5,851 \\
\hline INVINTANG & 564 & 1,388 & 11,001 & -1 & 175,225 \\
\hline \multicolumn{6}{|c|}{ Serbia } \\
\hline & OBS & MEAN & STD DEV & MIN & MAX \\
\hline PROF & 1103 & $-0,00460$ & 0,213 & $-0,959$ & 1 \\
\hline LIQ & 1226 & 0,0248 & 0,0513 & 0,00000417 & 0,417 \\
\hline SIZE & 1299 & 15,145 & 2,253 & 9,0607 & 18,965 \\
\hline AGE & 1358 & 30,450 & 24,525 & 1 & 172 \\
\hline INVTA & 1101 & 0,100 & 0,964 & $-0,824$ & 29,510 \\
\hline INVTANG & 1098 & 0,135 & 2,781 & -1 & 90,116 \\
\hline INVINTANG & 468 & 4,75 & 44,869 & -1 & 731,236 \\
\hline
\end{tabular}

\subsection{Determinants of Firm Investment}

The empirical results of the factors explaining the investment decision of firms are presented in Table 4 using data panels and ordinary least square methods. We found a highest correlation coefficient equal to $16.89 \%$ for the specification 1 for Moldova. However, specification 2 of country Romania has the lowest correlation coefficient of $-0.18 \%$.

Profitability: According to work of Lai Yung and Feng Yi (2015), we found a positive and a statistically significant effect of profitability on firm investment for specification 1 and 3 for country Romania and specification 1 for countries of Serbia and Moldova. This result is obtained, also, under specification 3 for country Russia. This result confirms the theory of free cash flow of Jensen (1986) which assumes that controlling shareholders try to reduce 
liquidity in the hands of managers by increasing investment. This result do not rejects our first hypothesis. However, profitability has a negative and statistically significant effect on firm investment for Moldova under specification 2. Therefore, we can conclude that with the increase in profitability, we notice an opportunistic behaviours of managers who try to take in private profits.

Liquidity: Like in Pawlina and Renneboog (2005) and Kazuo Ogawa (2015), liquidity positively and significantly affects firm investment under specification 1 and 2 for countries of Moldova and Serbia. This result has been theoretically supported by Jensen (1986). However, Dayong and Fang (2009), find a negative effect of cash holdings ratio. This result do not rejects our second hypothesis. However, we found a negative and not statistically significant effect of liquidity on firm investment for country Romania and Russia under specifications 2 and 3 respectively.

Size: Similarly to the results of Michelle, Rebecca and Rodrigo (2015), size variable positively and significantly affects the investment for countries of Russia and Serbia under specifications 1 and 2. However, this positive association is obtained under all specifications for Moldova country and first specification for country Romania. This result do not rejects our third hypothesis. However, we found a negative and not statistically significant effect of size on investment for country Romania under specifications 2 and 3. This inverse relationship means that for large firms, managers are not interested in allocating their surplus funds for investment.

Firm age: Similarly to the results of Massimo, Annalisa, Massimiliano (2013), the coefficient is negative and statistically significant under specifications 1 and 2 for two countries: Russia and Serbia. However, this effect is observed under the first specification for the other two countries. This result contradicts that presented by Kazuo Ogawa (2015). In fact, he found that factors explaining firm investment are not different between young and older firms. For country Moldova, we highlight a positive and statistically significant effect of firm age on investment decision.

Table 4. Firm investment determinants

\begin{tabular}{|c|c|c|c|c|c|c|}
\hline & \multicolumn{3}{|c|}{ Moldova } & \multicolumn{3}{|c|}{ Romania } \\
\hline & Specification 1 & Specification 2 & Specification 3 & Specification 1 & Specification 2 & Specification 3 \\
\hline & INVTA & INVTANG & INVINTANG & INVTA & INVTANG & INVINTANG \\
\hline $\mathrm{C}$ & $-4,698^{* * *}$ & $-28,525^{* * *}$ & $-4,998^{* *}$ & $5,769^{* * *}$ & 2,992 & $-1,250$ \\
\hline PROF & $0,415^{* * *}$ & $-20,110^{* * *}$ & $-0,788$ & $0,373^{*}$ & 0,253 & $24,335^{* * *}$ \\
\hline LEL & $0,824^{* * *}$ & $60,792^{*}$ & 0,149 & 0,235 & $-0,665$ & $-25,394$ \\
\hline SIZE & $0,399^{* * * *}$ & $1,478^{* *}$ & $0,281^{*}$ & $0,525^{* * *}$ & $-0,158$ & $-0,151$ \\
\hline AGE & $-0,0173^{* *}$ & $0,958^{* *}$ & 0,141 & $-0,115^{* * *}$ & 0,0080 & 0,556 \\
\hline OBS & 683 & 300 & 646 & 942 & 940 & 530 \\
\hline R squared (\%) & 16,89 & $4,13 \%$ & 0,37 & 6,01 & $-0,18$ & 0,89 \\
\hline \multirow[t]{4}{*}{ Prob $>$ F } & 0,0000 & 0,0025 & 0,1747 & 0,0000 & 0,6827 & 0,0697 \\
\hline & \multicolumn{3}{|c|}{ Russia } & \multicolumn{3}{|c|}{ Serbia } \\
\hline & Specification 1 & Specification 2 & Specification 3 & Specification 1 & Specification 2 & Specification 3 \\
\hline & INVTA & INVTANG & INVINTANG & INVTA & INVTANG & INVINTANG \\
\hline $\mathrm{C}$ & $-4,638^{* * *}$ & $-1,959^{* * *}$ & $-0,408$ & $-4,404^{* * *}$ & $-5,280^{* * *}$ & $-9,967$ \\
\hline PROF & 0,0364 & 0,0930 & $4,846^{*}$ & $0,261^{* * * *}$ & 0,188 & 1,104 \\
\hline LEL & 0,0122 & 0,156 & $-8,937$ & $1,483^{* * *}$ & $1,043^{*}$ & $-17,108$ \\
\hline SIZE & $0,437^{* * *}$ & $0,233^{* * *}$ & 0,0769 & $0,370^{* * *}$ & $0,449^{* * *}$ & 0,591 \\
\hline AGE & $-0,0708^{* * *}$ & $-0,0517^{* * *}$ & 0,0110 & $-0,0392^{* * * *}$ & $-0,0494^{* * *}$ & 0,165 \\
\hline OBS & 1015 & 1011 & 550 & 893 & 893 & 411 \\
\hline R squared(\%) & 10,46 & 5,71 & 0,24 & 16,25 & 7,36 & 0,04 \\
\hline Prob $>$ F & 0,0000 & 0,0000 & 0,2571 & 0,0000 & 0,0000 & 0,3831 \\
\hline
\end{tabular}

Note. ${ }^{* * *},{ }^{* * *}:$ significance at $10 \%, 5 \%$ and $1 \%$ levels respectively.

\section{Firm Investment and the Effect of Activity Sectors}

Similarly to the work of Varian (2001), Feenstra, Huang, and Hamilton (2003), Liu and Hsu (2006), Ronald, Sunglyong, and Youn (2008) and Subash, Lukose, and Surenderrao (2015), we examine the importance of the sectors in identifying factors explaining firm investment. The empirical results are presented in Table 5. We 
consider five business activities: The service sector, the real estate sector, the professionals activities, manufacturing and mining and agriculture activities. The empirical results are reported for our first measure of the dependent variable. For the country Russia, we found the highest correlation coefficient for the mining and agriculture sector at $87.46 \%$. In this case, variables size is positive and statistically significant. However, the coefficient of profitability variable is negative and statistically significant. The variable age influence negatively firm investment. This result means that young firms have higher investment ratio than mature firms. Furthermore, increased size leads to an increase in investment for the service sector firms. This result is similar to the professional activities. In addition, for this sector variable age have a negative effect on firm investment. Furthermore, we obtained a positive and a statistically significant effect of profitability on firm investment for all countries for two sectors. It appears that an increase in liquidity stimulates managers to invest more in the mining and agriculture sector in Russia. This same result is found for country Serbia for service, real estates and manufacturing sectors. However, the hypothesis of a positive effect between size and investment seems valid for all countries under all specifications, except for real estate sector for country Russia and professional activities for country Serbia. However, the reputation of a firm does not appear to stimulate managers to invest more for all market for every sector, except for the real estate, professionals activities, mining and agriculture sectors for country Moldova, and service and professionals activities for country Serbia.

Table 5. Firm investment determinants and effects of activity sectors

\begin{tabular}{|c|c|c|c|c|c|c|c|c|c|c|}
\hline & \multicolumn{5}{|c|}{ Moldova } & \multicolumn{5}{|c|}{ Romania } \\
\hline & $\begin{array}{c}\text { INVT } \\
\text { A } \\
\text { Service }\end{array}$ & $\begin{array}{l}\text { INTA } \\
\text { Real } \\
\text { estates }\end{array}$ & $\begin{array}{c}\text { INTA } \\
\text { Profession } \\
\text { als }\end{array}$ & $\begin{array}{l}\text { INTA } \\
\text { Man }\end{array}$ & $\begin{array}{c}\text { INVTA } \\
\text { min and } \\
\text { agr }\end{array}$ & $\begin{array}{l}\text { INVTA } \\
\text { Service }\end{array}$ & $\begin{array}{c}\text { INTA } \\
\text { Real } \\
\text { estates }\end{array}$ & $\begin{array}{c}\text { INTA } \\
\text { Profession } \\
\text { als }\end{array}$ & $\begin{array}{l}\text { INTA } \\
\text { Man }\end{array}$ & $\begin{array}{l}\text { INVTA } \\
\text { min and } \\
\text { agr }\end{array}$ \\
\hline $\mathrm{C}$ & $\begin{array}{c}-0,099 \\
8\end{array}$ & $-6,533^{* * *}$ & $-16,468^{* * *}$ & $-3,940^{* * *}$ & $-1,503^{* * *}$ & $-11,988^{* *}$ & $-2,970^{* *}$ & $-12,715^{* *}$ & $-4,626^{* * *}$ & $-2,445^{* * *}$ \\
\hline PROF & $0,355^{* *}$ & $0,588^{* * *}$ & 0,493 & 0,184 & 0,263 & 0,402 & $0,744^{* * * *}$ & 0,943 & $0,415^{* * *}$ & 0,0291 \\
\hline LEL & $-0,326$ & 0,687 & $-1,732$ & $-1,252$ & $-1,358$ & 1,132 & $-0,463$ & $-0,280$ & 0,235 & 0,159 \\
\hline SIZE & $\underset{* *}{0,0394}$ & $0,581^{* * *}$ & $1,503^{* * *}$ & $0,320^{* * *}$ & $0,115^{* * *}$ & $1,225^{* * *}$ & $0,298^{* * *}$ & $1,0706^{* *}$ & $0,386^{* * *}$ & $0,243^{* * *}$ \\
\hline AGE & $\begin{array}{c}-0,027 \\
3^{*}\end{array}$ & $-0,0205$ & 0,0279 & $-0,0219^{* *}$ & 0,0123 & $-0,326^{* * *}$ & $-0,079^{* * *}$ & $-0,187^{*}$ & $-0,0831^{* * *}$ & $-0,0397^{* * *}$ \\
\hline OBS & 142 & 187 & 32 & 269 & 53 & 180 & 104 & 36 & 444 & 178 \\
\hline R squared (\%) & 7,48 & 32,87 & 84,71 & 12,06 & 31,19 & 8,04 & 30,39 & 25,21 & 10,80 & 14,70 \\
\hline \multirow[t]{3}{*}{ Prob > F } & 0,0054 & 0,0000 & 0,0000 & 0,0000 & 0,0002 & 0,0163 & 0,0000 & 0,0979 & 0,0000 & 0,0002 \\
\hline & \multicolumn{5}{|c|}{ Russia } & \multicolumn{5}{|c|}{ Serbia } \\
\hline & $\begin{array}{c}\text { INVT } \\
\text { A } \\
\text { service } \\
\end{array}$ & $\begin{array}{c}\text { INTA } \\
\text { Real } \\
\text { estates } \\
\end{array}$ & $\begin{array}{c}\text { INTA } \\
\text { Profession } \\
\text { als } \\
\end{array}$ & $\begin{array}{l}\text { INTA } \\
\text { Man }\end{array}$ & $\begin{array}{c}\text { INVTA } \\
\text { min and } \\
\text { agr }\end{array}$ & $\begin{array}{l}\text { INVTA } \\
\text { Service }\end{array}$ & $\begin{array}{c}\text { INTA } \\
\text { Real } \\
\text { estates } \\
\end{array}$ & $\begin{array}{c}\text { INTA } \\
\text { Profession } \\
\text { als } \\
\end{array}$ & $\begin{array}{l}\text { INTA } \\
\text { Man }\end{array}$ & $\begin{array}{c}\text { INVTA } \\
\text { min and } \\
\text { agr }\end{array}$ \\
\hline $\mathrm{C}$ & $\begin{array}{c}-3,276^{*} \\
*\end{array}$ & $-0,647$ & $-8,794^{* * *}$ & $-4,139^{* * *}$ & $-3,909^{* * *}$ & $-7,722^{* * * *}$ & $-2,532^{* *}$ & 0,222 & $-3,804^{* * *}$ & $-6,83^{* * *}$ \\
\hline PROF & $0,342^{* *}$ & 0,238 & 0,240 & $0,243^{* *}$ & $-1,0213^{* * *}$ & 0,217 & 0,203 & $1,102^{* * *}$ & $0,359^{* * *}$ & $-0,0141$ \\
\hline LEL & 0,516 & 0,467 & 0,655 & 0,710 & $34,822^{* * *}$ & $3,131^{* * *}$ & $1,496^{* * * *}$ & 0,368 & $0,693^{*}$ & $-1,799$ \\
\hline SIZE & $\begin{array}{c}0,299^{* *} \\
*\end{array}$ & 0,117 & $0,641^{* * *}$ & $0,434^{* * *}$ & $0,235^{* * *}$ & $0,564^{* * *}$ & $0,343^{* * *}$ & 0,00671 & $0,319^{* * *}$ & $0,439^{* * *}$ \\
\hline AGE & $\underset{* *}{-0,049^{*}}$ & $-0,046^{* * *}$ & $-0,0837^{* * *}$ & $-0,071^{* * *}$ & $-0,00691^{*}$ & $-0,00909$ & $\begin{array}{c}-0,0758^{* *} \\
*\end{array}$ & $-0,00472$ & $-0,036^{* * *}$ & $-0,0200$ \\
\hline OBS & 111 & 68 & 183 & 627 & 26 & 206 & 193 & 33 & 410 & 51 \\
\hline $\begin{array}{l}\text { R squared } \\
(\%)\end{array}$ & 17,77 & 21,64 & 16,52 & 11,89 & 87,46 & 25,78 & 21,11 & 18,84 & 15,98 & 20,11 \\
\hline Prob> F & 0,0015 & 0,0095 & 0,0000 & 0,0000 & 0,0000 & 0,0000 & 0,0000 & 0,0420 & 0,0000 & 0,0618 \\
\hline
\end{tabular}

Note. ${ }^{* * *},{ }^{* * *}:$ significance at $10 \%, 5 \%$ and $1 \%$ levels respectively.

\section{Conclusion}

This paper interpret the factors explaining the investment decision of a firm (Galende\& Suarez, 1999; Galende \& 
Fuente, 2003). In particular, independent variables are; profitability, liquidity, size and firm age. Investment is measured alternatively by three ratios; change in total assets, changes in tangible fixed assets and changes in intangible fixed assets. The empirical validation was performed for four countries; Moldova, Romania, Russia and Serbia. Using the data panel estimation method, the empirical results pointed to differences between countries for the factors explaining investment decision, particularly profitability. In fact, we obtained positive and statistically significant effects in case of market Moldova, Russia and Serbia under specifications 1, 3 and 1, respectively. This result is found under specifications 1 and 3 for country Romania. A negative relation is obtained under specification 2 for country Moldova. Similarly, liquidity positively and significantly affects firm investment in Moldova and Serbia under specifications 1 and 2. The differences in the factors explaining investment is recorded, also, for size and firm age. Regarding the analysis of the sensitivity of our results by sectors, the empirical results show that the sectors significantly affect factors explaining investment, particularly, liquidity. Indeed, for the case of Russia, liquidity positively and significantly affects firm investment in the mining and agriculture sector. Furthermore, this result is found for service, real estate and manufacturing sectors for country Serbia.

\section{References}

Aghion, P., \& Howitt, P. (1992). A model of growth through creative destruction. Econometrica, 60, 323-351. http://dx.doi.org/10.2307/2951599

Alex, A. C., Hong, C., Dayong, Z., \& David, G. D. (2013). The impact of shareholding structure on firm investment: Evidence from Chinese listed companies. Pacific-Basin Finance Journal, 25, 85-100. http://dx.doi.org/10.1016/j.pacfin.2013.08.002

Almeida, H., Campello, M., \& Weisbach, M. S. (2004). The cash flow sensitivity of cash. Journal of Finance, 59, 1777-1804. http://dx.doi.org/10.1111/j.1540-6261.2004.00679.x

Arellano, M., \& Bond, S. R. (1991). Some tests of specification of panel data: Monte Carlo evidence and an application to employment equations. Review of Economic Studies, 58, 277-297.

Arellano, M., \& Bover, O. (1995). Another look at the instrumental-variable estimation of error component models. Journal of Econometrics, 68, 29-52. http://dx.doi.org/10.1016/0304-4076(94)01642-D

Bhagat, S., \& Welch, I. (1995). Corporate research and development investments: International comparisons. Journal of Accounting and Economics, 19, 443-470. http://dx.doi.org/10.1016/0165-4101(94)00391-H

Blundell, R., \& Bond, S. (1998). Initial conditions and moment restrictions in dynamic panel data models. Journal of Econometrics, 87, 115-143.

Bond, S., Harhofff, D., \& Van, R. J. (2005). Investment, R\&D and financial con-straints in Britain and Germany. Annalesd'Economieet de Statistique, 79(80), 435-462.

Bond, S., \& Meghir, C. (1994). Dynamic investment models and the firm's financial policy. Rev. Econ. Stud., 61, 197-222. http://dx.doi.org/10.2307/2297978

Bond, S., Elston, J. A., Mairesse, J., \& Mulkay, B. (2003). Financial factors and investment in Belgium, France, Germany, and the United Kingdom: A comparison using company panel data. Rev. Econ. Stat., 85, 153-165. http://dx.doi.org/10.1162/003465303762687776

Brown, J. R., Fazzari, S. M., \& Petersen, B. C. (2009). Financing innovation and growth: Cash flow, external equity and the $1990 \mathrm{~s}$ R\&D boom. Journal of Finance, 64(1), 151-185. http://dx.doi.org/10.1111/j.1540-6261.2008.01431.x

Chen, J. (2001). Ownership structure as corporate governance mechanism: Evidence from Chinese listed companies. Economics of Planning, 34, 53-72. http://dx.doi.org/10.1023/A:1017548432111

Clark, D. C. (2003). Corporate governance in China: An overview. China Economic Review, 14, 494-507. http://dx.doi.org/10.1016/j.chieco.2003.09.019

Cleary, S. (1999).The relationship between firm investment and financial status. Journal of Finance, 54, 673-692.

Czarnitzki, D., \& Hottenrott, H. (2010). Financing constraints for industrial innovation: What do we know? Review of Business and Economics, 55(3), 346-362. http://dx.doi.org/10.2139/ssrn.1621683

Dany, A., \& Junseok, H. (2008).The effects of cash flow and size on the investment decisions of ICT firms: A dynamic approach. Information Economics and Policy, 20, 120-134. http://dx.doi.org/10.1016/j.infoecopol.2007.12.001

David, F., Leonardo, F., Herbert, K., \& Eduardo, K. (2014). Innovation efforts and performances of Brazilian firms. 
Journal of Business Research, 67, 527-535. http://dx.doi.org/10.1016/j.jbusres.2013.11.009

Dayong, H., \& Wang, F. (2009). Cash, investments and asset returns. Journal of Banking \& Finance, 33, 2301-2311. http://dx.doi.org/10.1016/j.jbankfin.2009.06.006

David, B. A., \& Julie, A. E. (2002). Does firm size matter? Evidence on the impact of liquidity constraints on firm investment behavior in Germany. International Journal of Industrial Organization, 20, 1-17. http://dx.doi.org/10.1016/S0167-7187(00)00072-2

Duchin, R., Ozbas, O., \& Sensoy, B. A. (2010). Costly external finance, corporate investment and the subprime mortgage credit crisis. Journal of Financial Economics, 97, 420-435. http://dx.doi.org/10.1016/j.jfineco.2009.12.008

Farla, K. (2014). Determinants of firms' investment behaviour: A multilevel approach. Applied economics, 46, 4231-4241. http://dx.doi.org/10.1080/00036846.2014.955167

Fazzari, S. M., Hubbard, R. G., \& Petersen, B. C. (1988). Financing constraints and corporate investment. Brookings Papers on Economic Activity, I, 141-195. http://dx.doi.org/10.2307/2534426

Feenstra, R. C., Huang, D. S., \& Hamilton, G. G. (2003). A market-power based model of business groups. Journal of Economic Behavior \& Organization, 51, 459-485. http://dx.doi.org/10.1016/S0167-2681(02)00181-6

Galende, J., \& Fuente, J. M. (2003). Internal factors determining a firm's innovative behaviour. Research Policy, 32, 715-736. http://dx.doi.org/10.1016/S0048-7333(02)00082-3

Galende, J., \& Suarez, I. (1999). A resource-based analysis of the factors determining a firm's R\&D activities. Research Policy, 28(8), 891-905. http://dx.doi.org/10.1016/S0048-7333(99)00029-3

Harford, J. (1999). Corporate cash reserves and acquisitions. Journal of Finance, 52, 1969-1997. http://dx.doi.org/10.1111/0022-1082.00179

Heshmati, A. (2002). The dynamics of capital structure: Evidence from swedish micro and small firms. Research in Banking and Finance, 2, 199-241.

Hoshi, T., Kashyap, A., \& Scharfstein, D. (1991). Corporate structure liquidity and investment: Evidence from Japanese industrial groups. Quarterly Journal of Economics, 106, 33-60. http://dx.doi.org/10.2307/2937905

James R., Brown, A., \& Bruce, C. P. (2014). Which investments do firms protect? Liquidity management and real adjustments when access to finance falls sharply. Journal of Financial Intermediation.

Jensen, M. (1986). Agency costs offree cash flow,corporatefinance and takeovers. American Economic Review, 76, 323-329.

Kadapakkam, P., Kumar, P. C., \& Riddick, L. A. (1998). The impact of cash flows and firm size on investment: The international evidence. Journal of Banking \& Finance, 22(3), 293-320.

Kaplan, S. N., \& Zingales, L. (1997). Do investment-cash flow sensitivities provide useful measures of financing constraints? Quarterly Journal of Economics, 112, 169-215. http://dx.doi.org/10.1162/003355397555163

Kazuo, O. (2015). Firm Investment, Liquidity and Bank Health: A Panel Study of Asian Firms in the 2000s. Journal of Asian Economics. In Press, Accepted Manuscript, Available online 25 March 2015.

Liu, G. S., \& Sun, P. (2005). The class of shareholdings and its impacts on corporate performance: A case of state shareholding composition in Chinese public corporations. Corporate Governance: An International Review 13, 46-59. http://dx.doi.org/10.1111/j.1467-8683.2005.00402.x

Liu, W. C., \& Hsu, C. M. (2006). The role of financial development in economic growth: The experiences of Taiwan, Korea, and Japan. Journal of Asian Economics, 17, 667-690. http://dx.doi.org/10.1016/j.asieco.2006.06.007

Massimo, C. G., Annalisa, C., \& Massimiliano, G. (2013). The effect of public subsidies on firms' investment-cash flowsensitivity: Transient or persistent? Research Policy, 42, 1605-1623. http://dx.doi.org/10.1016/j.respol.2013.07.003

Michelle, H., Rebecca, L., \& Rodrigo, V. (2015). The effect of repatriation tax costs on U.S. multinational investment. Journal of Financial Economics, 116, 179-196. http://dx.doi.org/10.1016/j.jfineco.2014.12.004

Pawlina, G., \& Renneboog, L. (2005). Is investment-cash flow sensitivity caused by agency costs or asymmetric information? Evidence from the UK. European Financial Management, 11(4), 483-513. http://dx.doi.org/10.1111/j.1354-7798.2005.00294.x 
Qi, D., Wu, W., \& Zhang, H. (2000). Shareholding structure and corporate performance of partially privatized firms: Evidence from listed Chinese companies. Pacific-Basin Finance Journal, 8, 587-610. http://dx.doi.org/10.1016/S0927-538X(00)00013-5

Rajan, \& Luigi, Z. (1995). What Do We Know about Capital Structure? Some Evidence from International Data. The Journal of Finance, 50(5), 1421-1460. http://dx.doi.org/10.1111/j.1540-6261.1995.tb05184.x

Richard, E. B. (1977). The determinants of fixed investment by manufacturing firms in a developing country. International Economic Review, 18, 697-717. http://dx.doi.org/10.2307/2525956

Rebecca, Z. (2002). Evidence on the effects of bank competition on firm borrowing and investment. Journal of Financial Economics, 81, 503-537.

Ronald, A. R., Sunglyong, L., \& Youn, S. (2008). Bank concentration and financial constraints on firm-level investment in Europe. Journal of Banking \& Finance, 32, 2684-2694. http://dx.doi.org/10.1016/j.jbankfin.2008.07.001

Singh, M., \& Faircloth, S. (2005). The impact of corporate debt on long term investment and firm performance. Applied Economics, 37, 875-883. http://dx.doi.org/10.1080/00036840500076762

Subash, S., Lukoseb, P. J., \& Surenderrao, K. (2015). Financing constraints and investments in R\&D: Evidence from Indian manufacturing firms. The Quarterly Review of Economics and Finance, 55, 28-39. http://dx.doi.org/10.1016/j.qref.2014.07.002

Taeyoung, Y., \& Taeyoon, S. (2015). How outside directors facilitate corporate R\&D investment? Evidence from large Korean firms. Journal of Business Research, 68, 1251-1260. http://dx.doi.org/10.1016/j.jbusres.2014.11.005

Varian, H. R. (2001). Economics of information technology. Mimeo. University of California, Berkeley.

Xu, X. N., \& Wang, Y. (1999). Ownership structure and corporate governance in Chinese stock companies. China Economic Review, 10, 75-98. http://dx.doi.org/10.1016/S1043-951X(99)00006-1

Lai, Y. L., Lin, F. J., \& Lin, Y. H. (2015). Factors affecting firm's R\&D investment decisions. Journal of Business Research, 68, 840-844. http://dx.doi.org/10.1016/j.jbusres.2014.11.038

\section{Copyrights}

Copyright for this article is retained by the author(s), with first publication rights granted to the journal.

This is an open-access article distributed under the terms and conditions of the Creative Commons Attribution license (http://creativecommons.org/licenses/by/3.0/). 